\title{
Pengaruh Numbered Head Together Berbantuan Gambar Terhadap Penguasaan Kompetensi Pengetahuan IPA
}

\author{
Ni Luh Putu Diah Purwati ${ }^{1}$ I Md Citra Wibawa ${ }^{2}$, I Gd Margunayasa ${ }^{3}$ \\ ${ }^{123}$ Jurusan Pendidikan Guru Sekolah Dasar \\ Universitas Pendidikan Ganesha \\ Singaraja, Indonesia \\ e-mail: diahpurwati137@gmail.com ${ }^{1}$, imadecitra.wibawa@undiksha.ac.id ${ }^{2}$, \\ igede.margunayasa@undiksha.ac.id ${ }^{3}$
}

\begin{abstract}
Abstrak
Penelitian ini bertujuan untuk mengetahui perbedaan yang signifikan penguasaan kompetensi pengetahuan IPA antara siswa yang belajar menggunakan model pembelajaran numbered head together dan siswa yang belajar dengan menggunakan model pembelajaran konvensional. Jenis penelitian ini merupakan jenis penelitian kuasi eksperimen dengan rancangan penelitian digunakan adalah "Post Test Only Control Group Design". Populasi dalam penelitian ini adalah siswa kelas IV SD Negeri di gugus III Kecamatan Jembrana Tahun Ajaran 2017/2018. Sampel ditentukan dengan teknik cluster random sampling dan diperoleh SD Negeri 6 Dauhwaru sebagai kelompok eksperimen dan kelas IV SD Negeri 3 Dauhwaru sebagai kelompok kontrol. Data hasil penguasaan kompetensi pengetahuan IPA dikumpulkan menggunakan tes pilihan ganda. Data yang diperoleh dianalisis menggunakan teknik analisis statistik deskriptif dan statistik inferensian (uji-t) dengan rumus polled varians. Hasil penelitian menunjukkan bahwa terdapat perbedaan yang signifikan penguasaan kompetensi pengetahuan IPA antara siswa yang belajar dengan menggunakan model pembelajaran numbered head together berbantuan media gambar dan siswa yang belajar menggunakan model pembelajaran konvensional pada siswa kelas IV SD Negeri di Gugus III Kecamatan Jembrana Tahun Ajaran 2017/2018. Hal ini ditunjukkan oleh $t_{\text {hitung }}(2,07)>t_{\text {tabel }}(1,67)$ dan rata-rata (mean) kelompok eksperimen $(25,19)$ lebih besar dari rata-rata (mean) kelompok kontrol $(14,34)$. Ini berarti model pembelajaran numbered head together berbantuan media gambar berpengaruh terhadap penguasaan kompetensi pengetahuan IPA siswa kelas IV SD Negeri di Gugus III Kecamatan Jembrana.
\end{abstract}

Kata Kunci: Gambar, IPA, kompetensi, numbered head together

\begin{abstract}
This study aimed at investigating the significant difference of masterynatural science knowledge competence of the fourth grade of elementary school in Gugus III Kecamatan Jembrana in Academic Year 2017/2018 who were taught with Numbered Head Together assisted with picture media andthe students who were learning mastery of natural science knowledge taught conventionally. The study was quasi-experiment and designed in post-test only control group. The population of this study was 147 fourth-grade students of elementary schools of Gugus III Kecamatan Jembrana in Academic Year 2017/2018. The sample was obtained by conducting cluster random sampling technique. The sample of this study were 57 students, consisted of 25 students of SDN 3 Dauhwaru as control group and 32 students of SDN 6 Dauhwaru as experimental group.The obtained data of were analyze by using descriptive and inferential statistical analysis (t-test). The result of data analysis showed there was a significant effect on mastery natural science knowledge competence of fourth grades of elementary school Gugus III Kecamatan Jembrana in Academic Year 2017/2018 who were taught with NHT. The result of hypothesis testing with independent $t$-test showed that $t$ observed $(2,07)$ was higher than the $t$-critical value $(1,67)$ at the level of significance 0.05 . The result of data analysis showed that the mean score of the experimental group $(25,19)$ was higher than the mean score of control group $(14,16)$. It indicated that the effect of NHT with picture media on the fourth-grade of elementary school Gugus III Kecamatan Jembrana in Academic Year 2017/2018 was significant.
\end{abstract}

Keywords: NHT, Picture, Mastery knowledge science 


\section{Pendahuluan}

Pendidikan adalah hal terpenting bagi setiap negara untuk dapat berkembang pesat. Negara yang hebat akan menempatkan pendidikan sebagai prioritas pertamanya, karena dengan pendidikan, kemiskinan pada rakyat di negara tersebut akan dapat tergantikan menjadi kesejahteraan. Bagaimanapun, dalam perkembangannya, pendidikan di Indonesia senantiasa harus menghadapi beberapa masalah di setiap tahapnya. Masalahmasalah tersebut hanya dapat diselesaikan dengan partisipasi dari semua pihak yang terkait di dalam sistem pendidikan, seperti orangtua, guru-guru, kepala sekolah, masyarakat, dan juga peserta didik itu sendiri. Pada fase input, orangtua memiliki kontribusi besar dalam memperkenalkan nilai-nilai baik kepada anak-anak mereka. Orangtua bertanggung jawab penuh untuk mendidik anak-anak mereka dengan nilai-nilai kepemimpinan, sehingga mereka mempunyai bekal yang cukup untuk menjadi cikal bakal pemimpin ketika mereka mulai memasuki institusi formal, seperti sekolah. Pada fase proses, orangtua bekerjasama dengan para guru dan kepala sekolah untuk memberikan penguatan kepada peserta didik dalam menerapkan nilai-nilai kepempinan yang baik melalui budaya organisasi di sekolah. Terakhir, pada tahap output, peserta didik harus menghadapi begitu banyak tantangan di dunia nyata, di luar sekolah. Peserta didik yang sudah melalui tahap-tahap sebelumnya di sekolah dengan budaya organisasi yang mengajarkan dan membiasakan nilai-nilai baik dalam hidupnya, maka akan tumbuh menjadi pemimpin yang hebat untuk negara ini (Megawati, 2012).

Pendidikan secara etimologi berasal dari kata "paedagogie" dari bahasa Yunani, terdiri dari kata "pais" artinya anak dan "again" artinya membimbing, jadi jika diartikan, paedagogie artinya bimbingan yang diberikan kepada anak.1 Dalam bahasa Romawi pendidikan berasal dari kata "educate" yang berarti mengeluarkan sesuatu yang berada dari dalam.2 Sedangkan dalam bahasa Inggris pendidikan diistilahkan dengan kata "to educate" yang berarti memperbaiki moral dan melatih intelektual (Siti, 2018).

Pasal 1 UU SISDIKNAS no. 20 tahun 2003 disebutkan bahwa Sistem Pendidikan Nasional adalah keseluruhan komponen pendidikan yang saling terkait secara terpadu untuk mencapai tujuan pendidikan nasional. Berangkat dari bunyi pasal ini dapat diketahui bahwa pendidikan adalah sistem yang merupakan suatu totalitas struktur yang terdiri dari komponen yang saling terkait dan secara bersama menuju kepada tercapainya tujuan (Soetarno, 2003: 2). Adapun komponen-komponen dalam pendidikan nasional antara lain adalah lingkungan, sarana-prasarana, sumberdaya, dan masyarakat. Komponen-komponen tersebut bekerja secara bersama-sama, saling terkait dan mendukung dalam mencapai tujuan pendidikan. Tujuan pendidikan nasional yang dirumuskan dalam UU SISDIKNAS adalah untuk mengembangkan potensi anak didik agar menjadi manusia yang beriman dan bertakwa kepada Tuhan Yang Maha Esa, berakhlak mulia, sehat, berilmu, cakap, kreatif, mandiri, dan menjadi warga Negara yang demokratis serta bertanggung jawab (Munirah, 2015).

Seiring kemajuan jaman, segala aspek kehidupan juga ikut berubah tak terkecuali dalam aspek pendidikan. Salah satu bentuk perubahan yang terjadi yakni digantikannya kurikulum KTSP menjadi Kurikulum 2013. Dalam pengembangan Kurikulum 2013, pendekatan pembelajaran yang diterapkan dalam Kurikulum 2013 banyak mengalami perubahan yang bertujuan untuk mengoptimalkan perkembangan dan kemajuan pendidikan, salah satunya yakni diterapkannya pembelajaran yang menggunakan pendekatan saintifik (science approach). Hal yang diharapkan dari pengembangan Kurikulum 2013 yakni siswa menjadi lebih aktif dan menggali lebih banyak sendiri informasi di dalam pembelajaran di lingkungan sekolah maupun di luar sekolah. Harapan itu akan berdampak pada tujuan tercapainya Permendikbud No. 57 Tahun 2014 tentang Kurikulum 2013 yakni menciptakan generasi yang memiliki kepribadian, beriman, produktif, kreatif, serta berguna bagi bangsa. Untuk mewujudkan hal tersebut salah satu upaya yang dilakukan yakni dengan melakukan perbaikan pendekatan pembelajaran serta bahan pelajaran pada Kurikulum 2013 dibelajarkan secara tematik yang disempurnakan dan disederhanakan dari kurikulum KTSP. Salah satu muatan mata pelajaran pada struktur kurikulum 2013 di SD adalah mata pelajaran IPA. Samatowa (2016:58) menyatakan bahwa alasan IPA perlu dilaksanakan pada kurikulum sekolah karena 1) IPA berfaedah bagi suatu bangsa sebab IPA sebagai dasar teknologi, 2) IPA merupakan mata pelajaran yang melatih kemampuan berpikir kritis bila diajarkan menurut cara yang tepat, 3) bila diajarkan melalui percobaan, IPA bukanlah mata pelajaran yang bersifat hafalan belaka, dan 4) mata pelajaran IPA mempunyai nilai-nilai pendidikan yang dapat membentuk kepribadian siswa secara keseluruhan 
Begitu pentingnya muatan mata pelajaran IPA yang seharusnya menyenangkan dan digemari oleh siswa. Namun, kenyataannya IPA dianggap sulit. Permasalahan yang terjadi IPA tidak dipahami seutuhnya oleh siswa karena bentuk materi yang banyak menghafal yang menyebabkan rendahnya penguasaan kompetensi pengetahuan IPA siswa. Hal tersebut juga terjadi di SD Negeri Gugus III kecamatan Jembrana khususnya kelas IV. Hal ini diketahui setelah dilakukan wawancara serta pencatatan dokumen yang peneliti lakukan pada tanggal 24 November 2017 dengan beberapa guru di SD Negeri Gugus III Kecamatan Jembrana. Dalam wawancara yang telah dilakukan diperoleh informasi terdapat kendala yang menyababkan rendahnya penguasaan kompetensi pengetahuan IPA siswa diantaranya, yakni penyebab dari rendahnya penguasaan kompetensi pengetahuan IPA siswa kelas IV SD Negeri Gugus III Kecamatan Jembrana yakni, 1) guru menyatakan dalam pembelajaran guru menggunakan pembelajaran konvensional dengan menekankan teacher center karena hal tersebut dianggap oleh guru akan lebih cepat menyelesaikan pembelajaran, dan guru beranggapan siswa akan lebih cepat mengerti dengan apa yang guru sampaikan, 2) guru tidak menggunakan media pembelajaran karena menggunakan media pembelajaran disetiap pembelajaran akan membutuhkan banyak waktu untuk pembuatannya dan memerlukan biaya yang mahal, 3) beberapa guru kurang paham akan Kurikulum 2013 khususnya menautkan akan muatan pelajaran satu dengan muatan lainnya (tematik). Kendala lain juga diperkuat oleh penelitian yang dilakukan oleh Krissandi dan Rusnawan (2015) mengenai kendala guru sekolah dasar dalam imlpementasi kurikulum 2013 yang menyatakan bahwa (1) kendala kesulitan guru dalam menyiapkan media pembelajaran, (2) kendala pemahaman guru terhadap Kurikulum 2013 yang masih kurang menyeluruh, (3) kendala memadukan muatan dan mengajarkannya dalam naungan tema (tematik).

Selain wawancara, dilakukan pula observasi pada saat proses pembelajaran di dalam kelas yang dilakukan pada tanggal 24 november 2017, ditemukan beberapa permasalahan dalam proses pembelajaran diantaranya, 1) Dalam proses belajar mengajar guru tidak menerapkan model pembelajaran yang inovatif, proses belajar mengajar yang

dilaksanakan cenderung hanya menggunakan pembelajaran konvensional yang didominasi oleh guru melakukan pembelajaran dengan ceramah dan pemberian latihan soal diakhir kegiatan pembelajaran, tanpa memeberikan kesempatan yang lebih banyak kepada siswa untuk menggali informasi mengenai materi yang diajarkan sehingga pembelajaran terkesan kurang berbakna bagi siswa. Hal tersebut sangat tidak sesuai dengan pembelajaran yang sedang dikembangkan yakni pembelejaran Kurikulum 2013, kegiatan belajar yang seharusnya didominasi oleh siswa seperti berdiskusi, berargumen, serta memberikan kesempatan kepada siswa untuk menyampaikan pemikirannya tidak terwujud, yang dikarenakan adanya pola belajar yang lebih menekankan pada teacher center bukan student center. Hal tersebut menyebabkan siswa menjadi kurang antusias dalam mengikuti pembelajaran, yang menyebabkan beberapa siswa melakukan kegiatan yang tidak seharusnya dilakukan pada saat pembelajaran, seperti mengganggu teman, serta beberapa siswa terlihat bosan yang berdampak pada konsentrasi siswa cepat menurun, 2) selama proses belajar mengajar berlangsung tidak terlihat adanya penggunaan media pembelajaran yang digunakan, selama proses pembelajaran yang digunakan hanya buku ajar saja.

Catatan dokumen yang peneliti peroleh di SD Negeri Gugus III Kecamatan Jembrana berupa nilai hasil Ulangan Tengah Semester (UTS). Memperlihatkan bahwa penguasaan kompetensi pengetahuan IPA siswa kelas IV sangat rendah. Adapun data nilai siswa sebagai berikut.

Tabel 1. Penguasaan Kompetensi Pengetahuan IPA Siswa Kelas IV Berdasarkan Nilai UTS Semester Ganjil Tahun Ajaran 2017/2018.

\begin{tabular}{llllllll}
\hline \multirow{2}{*}{ NO Nama Sekolah } & \multirow{2}{*}{ KKM } & \multirow{2}{*}{ Jumlah } & \multicolumn{2}{l}{$\begin{array}{l}\text { Siswa } \\
\text { mencapai KKM }\end{array}$} & $\begin{array}{l}\text { Siswa yang belum } \\
\text { mencapai KKM }\end{array}$ \\
\cline { 5 - 8 } & & & Siswa $\%$ & Siswa & $\%$ \\
\hline 1 & SDN 1 Dauhwaru & 70 & 14 & 4 & $28 \%$ & 10 & $72 \%$ \\
\hline 2 & SDN 2 Dauhwaru & 70 & 20 & 8 & $40 \%$ & 12 & $60 \%$ \\
\hline 3 & SDN 3 Dauhwaru & 70 & 50 & 21 & $42 \%$ & 29 & $58 \%$ \\
\hline 4 & SDN 4 Dauhwaru & 70 & 16 & 6 & $37,5 \%$ & 10 & $6325 \%$ \\
\hline 5 & SDN 5 Dauhwaru & 70 & 15 & 6 & $40 \%$ & 9 & $60 \%$ \\
\hline 6 & SDN 6 Dauhwaru & 70 & 32 & 12 & $37,5 \%$ & 20 & $62,5 \%$ \\
& Rata-rata & & 25 & 3 & $37,5 \%$ & 15 & $62,5 \%$ \\
\hline
\end{tabular}


Berdasarkan pemaparan Tabel 1., diketahui bahwa rata-rata jumlah siswa tiap kelas di Gugus III Kecamatan Jembrana adalah 25 orang. Terlihat bahwa jumlah siswa yang belum mencapai KKM lebih banyak jumlahnya yaitu rata-rata sebanyak $62,5 \%$ atau setara dengan 15 orang dari rata-rata 25 orang. Hal ini membuktikan bahwa penguasaan kompetensi IPA siswa di wilayah Gugus III Kecamatan Jembrana, cenderung rendah atau belum mencapai Kriteria Ketuntasan Minimum (KKM) yang menjadi standar tercapainya tujuan pembelajaran yang harus dikuasai siswa. Rendahnya penguasaan kompetensi pengetahuan IPA siswa semakin membuktikan bahwa anggapan IPA itu masih sulit bagi siswa khususnya siswa kelas IV SD Negeri Gugus III Kecamatan Jembrana.

Salah satu alternatif yang dapat dilakukan untuk meningkatkan penguasan pengetahuan IPA siswa kelas IV di SD Gugus III Kecamatan Jembrana adalah seorang guru dalam menyampaikan materi perlu memilih model yang sesuai dengan keadaan kelas atau siswa sehingga siswa merasa tertarik untuk mengikuti pembelajaran yang diajarkan. Mencermati hal tersebut, perlu adanya perubahan dan pembaharuan, inovasi ataupun gerakan perubahan mind set kearah pencapaian tujuan pendidikan. Pembelajaran hendaknya lebih bervariasi model maupun strateginya guna mengoptimalkan potensi siswa.

Menurut Japa dan Suarjana (2015) salah satu model pembelajaran yang sesuai diterapkan pada Kurikulum 2013 adalah model pembelajaran kooperatif (cooperative Learning). Model pembelajaran tersebut akan memberikan siswa kesempatan yang lebih banyak untuk melakukan aktivitas yang menyenangkan melalui bentuk interaksi dan kerjasama, seperti melakukan penemuan yang dilakukan dengan percobaan, sehingga kegiatan siswa cenderung untuk mencari tahu tentang prinsip konsep pengetahuan, bukan menunggu diberikan oleh guru

Salah satu jenis pembelajaran kooperatif yang tepat digunakan dalam pembelajaran Kurikulum 2013. Model numbered head together selain menekankan pembelajaran dalam bentuk diskusi kelompok, model ini juga menekankan pada kemampuan berpikir kritis siswa hal tersebut sejalan dengan alasan perlunya IPA diajarkan dalam kurikulum pembelajaran yakni IPA melatih daya berpikir kritis siswa, hal tersebut akan berdampak pada meningkatnya kemampuan siswa untuk menguasai kompetensi pengetahuan slah satunya pengetahuan IPA. Selain itu, model numbered head together memiliki kelebihan jika diterapkan Purnomo (2012) menyatakan "NHT has several advantages. First, it can improve students' academic achievement and applied to almost all subject areas. Second, it can increase students' equel participation will be apparent. Fourt, it motivates students to learn. Fifth, it encourages peer tutoring from smart student who know the answer to other team member who do not". Berdasarkan hal tersebut pembatasan antara siswa yang pintar dengan yang kurang pintar dapat diatasi, serta dengan model NHT siswa yang kurang pintar akan memiliki motivasi belajar yang lebih tinggi yang nantinya akan berdampak pada pencapaian hasil belajar siswa.

Pembelajaran yang inovatif akan lebih optimal apabila di dukung dengan penggunaan media. Memanfaatkan media akan menjadikan pembelajar dapat berjalan dengan maksimal, penggunaan media pembelajaran dapat membantu siswa untuk lebih mudah memahami pembelajaran. Salah satu media pembelajaran yang mendukung optimal kegiatan belajar mengajar yakni dengan menggunakan media gambar berupa foto-foto yang sifatnya hampir menyerupai aslinya. Gambar memiliki kelebihan seperti mudah diperoleh, praktis, serta murah hal tersebut diperkuat oleh pendapat Sadiman (2015:30) "gambar merupakan media yang murah dan sangat mudah untuk diperoleh". Media gambar juga mampu mengoptimalkan rasa ingin tahu siswa, keaktifan siswa, serta menghindarkan siswa dari pebelajaran yang bersifat abstrak. Penggunaan media gambar membantu siswa untuk lebih mudah untuk memahami materi yang diajarkan terlebih pada pembelajaran Kurikulum 2013.

Oleh karena itu, mengkombinasikan model pembelaran Numbered Head Together berbantuan media gambar dalam pembelajaran akan dapat menciptakan suasana belajar yang menarik, siswa lebih aktif, dan menumbuhkan rasa ingin tahu yang besar, sehingga penguasaan kompetensi pengetahuan IPA siswa dapat lebih optimal yang akan berdampak pada maningkatnya hasil belajar siswa khususnya pada IPA.

Berdasarkan latar belakang diatas, dilakukan penelitian dengan judul Pengaruh Model Pembelajaran Numbered Head Together Berbantuan Media Gambar Terhadap Penguasaan Kompetensi Pengetahuan IPA pada Siswa Kelas IV SD Negeri Gugus III Kecamatan Jembrana Tahun Ajaran 2017/2018. 


\section{Metode}

Penelitian ini dilaksanakan di SD Gugus III Kecamatan Jembrana tahun ajaran 2017/2018. Penelitian ini merupakan penelitian eksperimen semu (quasi experiment). Desain penelitian ini bertujuan untuk menguji pengaruh suatu model pembelajaran dengan cara menerapakan treatment pada kelas eksperimen dan membandingkan hasilnya dengan kelas kontrol. Rancangan penelitian ini menggunakan rancangan non-equivalen post-test only control group design. Secara prosedural desain penelitian ini disajikan sebagai berikut.

Tabel 2. Desain Penelitian

\begin{tabular}{lll}
\hline Kelas & Treatment & Post-test \\
\hline Eksperimen & $\mathrm{X}$ & $\mathrm{O}_{1}$ \\
Kontrol & - & $\mathrm{O}_{2}$ \\
\hline
\end{tabular}

Keterangan:

(Sumber: Sugiono, 2017:112)

$\mathrm{X} \quad=$ Perlakuan yaitu model pembelajaran NHT

$\mathrm{O}_{1} \quad=$ Tes akhir (post-test) kelompok eksperimen

$\mathrm{O}_{2} \quad=$ Tes akhir (post-test) kelompok kontrol.

Populasi dalam penelitian ini adalah seluruh siswa kelas IV di SD Negeri Gugus III Kecamatan Jembrana tahun ajaran 2017/2018 sebanyak 6 sekolah dengan jumlah 147 siswa. Untuk menentukan sampel penelitian ini, pada tahap awal dilakukan uji kesetaraan dengan taraf signifikansi $5 \%$ terhadap populasi penelitian. Berdasarkan uji kesetaraan menggunakan ANAVA A, diperoleh hasil bahwa tidak terdapat perbedaan yang signifikan nilai penguasaan kompetensi pengetahuan IPA siswa kelas IV SD Negeri di Gugus III Kecamatan Jembrana. Hal ini menunjukkan bahwa bahwa hasil nilai penguasaan kompetensi pengetahuan IPA siswa kelas IV dari enam sekolah di Gugus III Kecamatan Jembrana semua setara. Selanjutnya, dari enam SD yang ada di Gugus III Kecamatan Jembrana, maka diambil dua kelas dengan cara random sampling/undian yang diperoleh hasil, yaitu SDN 3 Dauhwarudan SDN 6 Dauhwaru. Untuk menentukan kelas eksperiemn dan kontrol, dilakukan dengan cara pengundian kembali dengan hasil, SDN 3 Dauhwaru sebagai kelas kontrol dengan diberikan perlakuan menggunakan model pembelajaran konvensional dan SDN 6 Dauhwaru sebagai kelas eksperimen dengan menggunakan model pembelajaran NHT berbantuan Media Gambar.

Data yang diperlukan dalam penelitian ini adalah data hasil penguasaan kompetensi pengetahuan IPA siswa kelas IV. Dalam penelitian ini, metode yang digunakan untuk mengumpulkan data adalah metode tes dengan menggunakan tes pilihan ganda. Tes pilihan ganda digunakan pada saat post-tes. Tes pilihan ganda yang dipergunakan untuk mengumpulkan data hasil penguasaan kompetensi pengetahuan IPA pada siswa kelas IV SDN di Gugus III Kecamtan Jembrana ini sebanyak 30 butir soal dengan empat alternatif jawaban (a, b, c, dan d) yang dapat dilipilih oleh siswa. Setiap item akan diberikan skor 1 (satu) bila siswa menjawab dengan benar (jawaban cocok dengan kunci jawaban). Serta skor 0 (nol) untuk siswa yang menjawab salah.

Teknik analisis data yang digunakan dalam penelitian ini adalah teknik analisis deskriptif yang digunakan untuk mencari skor rata-rata/mean, median, modus, standar deviasi (SD), dan varians terhadap kelompok eksperimen dan kontrol. Mean, median, modus data penguasaan kompetensi pengetahuan IPA siswa kemudian disajikan dalam garfik poligon. Teknik analisis statistik inferensial dilakukan dua pengujian, yaitu uji prasyarat dan uji hipotesis. Uji prasyarat analisis ini dilakukan untuk memperoleh fakta apakah data memenuhi prasyarat homogenitas varians dan normalitas sebaran. Untuk menguji hipotesis penelitian digunakan analisis uji-t $(t-$ test) dengan rumus polled varians. Rumus polled varians digunakan dalam uji hipotesis penelitian ini karena jumlah anggota sampel pada kelompok eksperimen dan kelompok kontrol tidak sama, serta varians homogen.

\section{Hasil dan Pembahasan}

Data hasil penguasaan kompetensi pengetahuan IPA siswa diperoleh dari hasil post-test yang telah diberikan kepada kedua kelompok sampel. Hasil post-test terhadap 25 orang siswa kelas IV di SDN 3 Dauhwaru yang dibelajarkan menggunakan model pembelajaran konvensional pada kelompok kontrol tabel 3 sebagai berikut. 
Tabel 3. Hasil post-test Kelompok Kontrol

\begin{tabular}{cc}
\hline Keterangan & Hasil \\
\hline Modus & 14,16 \\
Median & 14,21 \\
Mean & 14,34 \\
Standar Deviasi & 2,77 \\
Varian & 7,71 \\
\hline
\end{tabular}

Mean, median, dan modus hasil penguasaan kompetensi pengetahuan IPA kelompok kontrol, selanjutnya disajikan ke dalam grafik poligon. Tujuan penyajian data ini adalah untuk menafsirkan sebaran data hasil keterampilan membaca intensif pada kelompok eksperimen.

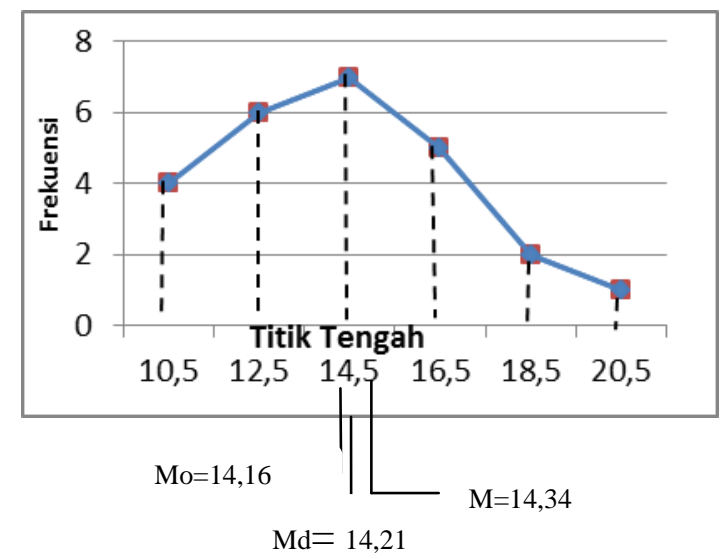

Gambar 1. Grafik Poligon Data Penguasaan Kompetensi Pengetahuan Kelompok Kontrol

Berdasarkan grafik poligon pada gambar 1 tampak bahwa kurva sebaran data kelompok eksperimen menunjukkan juling positif karena mean lebih besar dari median dab modus lebih besar dari mean ( $\mathrm{M}>\mathrm{Md}>\mathrm{Mo}$ ) yaitu 14,34>14,21>14,16. Hal ini menunjukkan bahwa sebagain besar skor cenderung tinggi. Jika dikonversikan ke dalam PAP skala Lima data keterampilan membaca intensif kelompok eksperimen berada pada kategori sedang. Data penguasaan kompetensi pengetahuan siswa yang diperoleh dari hasil post-test terhadap 32 orang siswa kelas IV di SDN 6 Dauhwaru yang dibelajarkan menggunakan model pembelajaran NHT berbantuan media gambar pada kelompok eksperimen ditunjukkan pada tabel 4 sebagai berikut.

Tabel 4. Hasil post-test Kelompok Eksperimen

\begin{tabular}{cc}
\hline Keterangan & Hasil \\
\hline Modus & 25,50 \\
Median & 25,40 \\
Mean & 25,19 \\
Standar Deviasi & 2,55 \\
Varian & 6,52 \\
\hline
\end{tabular}

Mean, median, dan modus hasil penguasaan kompetensi pengetahuan kelompok ekaperimen, selanjutnya disajikan ke dalam grafik poligon. Tujuan penyajian data ini adalah untuk menafsirkan sebaran data hasil penguasaan kompetensi pengetahuan pada kelompok eksperimen. 


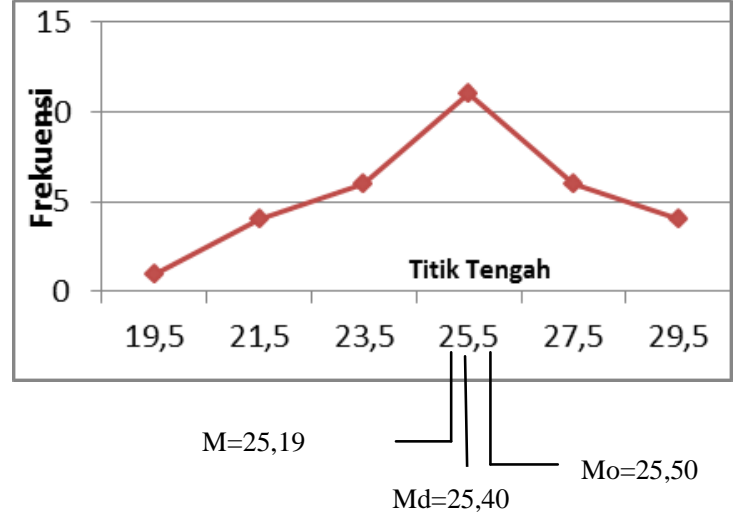

Gambar 2. Grafik Poligon Data penguasaan kompetensi pengetahuan Kelompok Eksperimen.

Berdasarkan grafik poligon pada gambar 2 tampak bahwa kurva sebaran data kelompok eksperimen menunjukkan juling negatif karena modus lebih besar dari median dan mean lebih kecil dari mean $(M<M d<M o)$ yaitu $25,19<25,40<25,5$. Hal ini menunjukkan bahwa sebagain besar skor cenderung tingi. Jika dikonversikan ke dalam PAP skala Lima data penguasaan kompetensi pengetahuan kelompok eksperimen berada pada kategori sangat tinggi.

Sebelum dilanjutkan pada pengujian hipotesis, terlebih dahulu dilakukan pengujian asumsi terhadap data yang diperoleh meliputi uji normalitas sebaran data dan uji homogenitas varians. Berdasarkan penghitungan data hasil penguasaan kompetensi pengetahuan dengan menggunakan rumus chi-kuadarat, diperoleh $x^{2}$ hitung hasil post-test kelompok eksperimen adalah 2,285 dan $x_{\text {tabel }}^{2}$ dengan taraf signifikansi $5 \%$ dan $\mathrm{db}=2$ adalah 7,815. Hal ini menunjukkan $x^{2}$ hitung hasil post-test kelompok eksperimen lebih kecil dari $x_{\text {tabel. }}^{2}$ Sehingga data hasil post-test kelompok eksperimen berdistribusi normal.

Hasil penghitungan data hasil penguasaan kompetensi pengetahuan dengan menggunakan rumus chi-kuadarat, diperoleh $x^{2}$ hitung hasil post-test kelompok kontrol adalah 2,028 dan $x_{\text {tabel }}^{2}$ dengan taraf signifikansi $5 \%$ dan $\mathrm{db}=2$ adalah 7,815 . Hal ini menunjukkan $x^{2}$ hitung hasil post-test kelompok kontrol lebih kecil dari $x^{2}$ tabel. Sehingga data hasil post-test kelompok kontrol berdistribusi normal.

Selanjutnya, uji homogenitas dilakukan terhadap varians pasangan antar kelompok eksperimen dan kontrol. Uji yang digunakan adalah uji- $F$ dengan kriteria data homogen jika $F_{\text {hitung }}<F_{\text {tabel. }}$ Berdasarkan hasil penghitungan, diperoleh $F_{\text {hitung }}$ data hasil penguasaan kompetensi pengetahuan siswa kelompok eksperimen dan kelompok kontrol adalah 1,18. Sedangkan $\mathrm{F}_{\text {tabel }}$ dengan $\mathrm{db}_{\text {pembilang }}=24, \mathrm{db}_{\text {penyebut }}=31$, dan taraf signifikansi $5 \%$ adalah 1,87 . Hal ini berarti $F_{\text {hitung }}<F_{\text {tabel }}$ sehingga varians data hasil penguasaan kompetensi pengetahuan IPA siswa kelompok eksperimen dan kelompok kontrol adalah homogen.

Berdasarkan uji prasyarat analisis data, diperoleh bahwa data hasil penguasaan kompetensi pengetahuan IPA siswa kelompok eksperimen dan kelompok kontrol adalah normal dan homogen. Setelah diperoleh hasil dari uji prasyarat analisis data, dilanjutkan dengan pengujian hipotesis penelitian. Hipotesis yang diuji adalah pengaruh yang signifikan antara kelompok siswa yang dibelajarkan dengan menggunakan model pembelajran NHT berbantuan media gambar dengan kelompok siswa yang dibelajarkan menggunakan model pembelajaran konvensional terhadap penguasaan kompetensi pengetahuan IPA. Pengujian hipotesis tersebut dilakukan dengan menggunakan uji-t sampel independent (tidak berkolerasi) dengan rumus polled varians dengan kriteria $\mathrm{H}_{0}$ tolak jika $t_{\text {hitung }}>t_{\text {tabel }}$ dan $\mathrm{H}_{1}$ terima jika $t_{\text {hitung }}<t_{\text {tabel. }}$. Ringkasan uji hipotesis disajikan pada tebl 5 .

Tabel 5. Ringkasan Hasil Uji Hipotesis

\begin{tabular}{lcccccc}
\hline Kelompok & $\mathrm{N}$ & $\mathrm{Db}$ & Mean & $\mathrm{s}^{2}$ & $\mathrm{t}_{\text {hit }}$ & $\mathrm{t}_{\text {tab }}$ \\
\hline Eksperimen & 32 & \multirow{2}{*}{55} & 25,19 & 6,52 & \multirow{2}{*}{2,07} & 1,67 \\
Kontrol & 25 & & 14,34 & 7,71 & 2,07 \\
\hline
\end{tabular}

Hasil penghitungan uji-t diperoleh $t_{\text {hitung }}$ sebesar 2,07. Sedangkan $t_{\text {tabel }}$ dengan $d b=47$ dan taraf signifikansi $5 \%$ adalah 1,67 . Hal ini berarti $t_{\text {hitung }}$ lebih besar dari $t_{\text {tabel }}\left(t_{\text {hitung }}>t_{\text {tabel }}\right)$ sehingga $\mathrm{H}_{0}$ ditolah dan $\mathrm{H}_{1}$ dterima. Dengan demikian, dapat diinterpretasikan bahwa terdapat 
perbedaan yang signifikan antara kelompok siswa yang dibelajarkan menggunakan model pembelajaran NHT berbantuan media gambar dengan kelompok siswa yang dibelajarkan menggunakan model pembelajaran konvensional terhadap penguasaan kompetensi pengetahuan IPA pada siswa kelas IV SD Negeri di Gugus III Kecamatan JembranaTahun Ajaran 2017/2018.

Hasil analisis data penguasaan kompetensi pengetahuan IPA siswa menunjukkan bahwa terdapat perbedaan yang signifikan penggunaan model pembelajaran NHT berbantuan media gambar terhadap penguasaan kompetensi pengetahuan IPA siswa kelas IV SD Negeri di Gugus III Kecamatan Jembrana Tahun Ajaran 2017/2018.

Pertama, model pembelajaran NHT membuat perhatian siswa meningkat, hal tersebut dikarenakan adanya penunjukkan siswa secara acak oleh guru dengan cara guru menyebutkan salah satu nomor (Numbering) yang menjadi identitas mereka dalam kelompok untuk menyampaikan hasil diskusi, sehingga kesiapan serta tanggung jawab setiap siswa dituntut dalam proses pembelajaran hal tersebut berdampak pada penguasaan kompetensi pengetahuan siswa. Kedua, guru aktif memberikan pertanyaan-pertanyaan yang dapat mendorong siswa untuk mengoptimalkan kemampuan berfikir kritis siswa terhadap suatu permasalahan baik itu berupa pertanyaan-pertanyaan sederhana yang biasa ditemukan siswa dalam kehidupan sehari-hari, hal tersebut akan berdampak pada kemampuan siswa yakni akan meningkatkan kemampuan menganalisis dan kemampuan menyimpulkan siswa. Dengan membiasakan berfikir kritis akan tercipta siswa-siswa yang kreatif dan inovatif hal tersebut sejalan dengan pendapat Kurniasih dan Berlin (2014:7) "berfikir kritis dapat membentuk generasi produktif, kreatif, inovatif, dan afektif". Selain itu juga guru memberikan kesempatan bagi siswa untuk mengeksplor rasa ingin tahu siswa melalui memberikan kesempatan kepada siswa untuk bertanya mengenai hal-hal yang berkaitan dengan materi yang diajarkan serta berkaitan dengan kehidupan sehari-hari siswa, baik dilingkungan sekolah maupun lingkungan rumah, hal tersebut akan berdampak pada antusias siswa untuk ikut terlibat dalam pembelajaran sehingga mendorong siswa untuk aktif yang berdampak pada meningkatnya pemahaman siswa akan materi yang di belajarkan. Hal tersebut sejalan dengan pendapat Trianto (2014) bahwa, suatu materi yang diajarkan kepada siswa akan bertambah berarti jika siswa mempelajari materi yang dekat dengan kehidupan sehari-hari. Ketiga, Pembelajaran NHT menekankan siswa lebih banyak belajar dalam bentuk kelompok untuk menyelesaikan permasalahan dengan pola pikir siswa masing-masing melalui diskusi dan bertukar informasi, kemudian menyatukan ide-ide mereka (Head Together), hal tersebut berdampak pada semakin optimalnya hasil belajar siswa khususnya dalam hal menguasai materi yang sedang dipelajari siswa sehingga penguasaan kompetensi pengetahuan dapat dicapai siswa melalui hasil belajar yang diambil dari nilai post-test, selain itu juga dapat meningkatkan rasa empati siswa terutama antar siswa yang kurang dari segi pengetahuan hal tersebut sejalan dengan pernyataan Purnomo (2012) yang menyatakan "NHT encourages peer tutoring from smart student who know the answer to other team member who do not". Keempat, pada saat guru meminta jawaban dari persoalan yang tengah dibahas, siswa berani menyampaikan hasil diskusikan pada masing-masing kelompok, bahkan siswa yang berasal dari kelompok lain juga berani menyampaikan hasil diskusi kelompok mereka hal tersebut berdampak pada meningkatnya rasa percaya diri siswa. Kelima, mengkombinasikan model pembelajaran NHT dengansalah satu media sebagai alat bantu siswa atau guru agar lebih mudah menguasai materi yang ingin disampaikan guru kepada siswa juga berdampak positif, hal tersebut terbukti pada saat guru menunjukan beberapa gambar, reaksi siswa pada saat menjawab sangat beragam dan menciptakan suasana kelas sangat aktif dikarenakan siswa menjawab dengan beragam jawaban yang berasal dari apa yang mereka lihat dan mereka ketahui. Adanya gambar juga lebih meningkatkan perhatian siswa, karena siswa merasa tertarik dan berdampak pada motivasi siswa untuk dapat meningkatkan kemampuan menganalisis. Hal tersebut didukung oleh pendapat Sudjana dan Rivai (dalam Asyad, 2007) yang menyatakan salah satu manfaat gambar adalah "Pembelajaran lebih menarik perhatian siswa dan dapat menumbuhkan motivasi belajar". Berdasarkan hal tersebut, bahwa pembelajaran dengan menggunakan model NHT memberikan hasil yang lebih baik daripada pembelajaran yang menggunakan model pembelajaran konvensional, sehingga berpengaruh terhadap penguasaan kompetensi pengetahuan IPA siswa kelas IV SD Negeri Gugus III Kecamatan Jembrana Tahun Ajaran $2017 / 2018$.

Dengan demikian pembelajaran ini dapat diterapkan sebagai variasi dalam kegiatan pembelajaran sehingga siswa tidak mudah jenuh dan bosan, sehingga pembelajaran bisa menjadi lebih variatif yang akan berdampak pada hasil belajar siswa. 


\section{Simpulan dan Saran}

Berdasarkan hasil pengujian hipotesis dan pembahasan, maka temuan dalam penelitian ini menyatakan bahwa terdapat perbedaan yang signifikan penguasaan kompetensi pengetahuan IPA antara kelompok siswa yang menggunakan model pembelajaran NHT berbantuan media gambar dan kelompok siswa yang menggunakan model pembelajaran konvensional. Hasil analisis menunjukkan bahwa skor rata-rata (mean) kelompok eksperimen yakni 25,19 lebih besar dari skor rata-rata (mean) kelompok kontrol yakni 14,43 dan kualifikasi penguasaan kompetensi pengetahuan IPA siswa yang menggunakan model pembelajaran NHT berbantuan media gambarberada pada kategori sangattinggi sedangkan penguasaan kompetensi pengetahuan IPA siswa yang menggunakan model pembelajaran konvensional berada pada kategori sedang.

Maka dapat disimpulkan bahwa pembelajaran dengan model pembelajaran NHT berbantuan media gambar berpengaruh positif terhadap penguasaan kompetensi pengetahuan IPA kelas IVdi SD NegeriGugus III Kecamatan Jembrana Tahun Ajaran 2017/2018.

Saran yang dapat disampaikan berdasarkan penelitian yang telah dilakukan adalah kepada siswa dalam mengikuti proses pembelajaran diharapakan selalu terlibat secara aktif di setiap kegiatan belajar. Siswa yang memiliki pengetahuan lebih baik dari siswa yang kurang agar mau membantu atau mampu menjadi tutor sebaya bagi siswa yang kurang dalam hal menguasai materi yang diajarkan agar nantinya dapat meningkatkan penguasaan kompetensi pengetahuan dan mendapatkan pengetahuan baru melalui pengalaman yang ditemukan pada saat proses pembelajaran.

Kepda gurudiharapkan terus mencoba dan lebih sering menerapkan model pembelajaran $\mathrm{NHT}$ berbantuan media gambar dalam muatan pelajaran IPA ataupun dapat juga digunakan pada muatan pelajaran lain yang dirasakan sesuai, sehingga hasil yang dicapai menjadi lebih baik.

Kepada sekolah diharapkan agar lebih sering memberikan kegiatan pelatihan kepada guruguru lainnya mengenai model pembelajaran NHT disertai penggunaan media belajar berupa gambar, sehingga dapat diterapkan disemua kelas pada saat muatan pelajaran IPAatau muatan pelajaran lainnya dan manfaat dari model pembelajaran NHT dapat dirasakan oleh semua warga sekolah.

Peneliti lain yang akan mengadakan penelitian lebih lanjut tentang pembelajaran NHT berbantuan media gambar dalam bidang pelajaran IPA maupun pelajaran lainnya diharapkan menambah variabel-variabel yang akan diteliti, baik variabel bebas atau variabel terikat dan dapat melaksanakan penelitian untuk muatan pelajaran selain IPA.

\section{Daftar Pustaka}

Agung, A.A Gede. 2014. "Metodelogi Penelitian Pendidikan". Singaraja : Fakultas IImu Pendidikan, Universitas Pendidikan Ganesha.

Arikunto, Suharsimi. 2013. "Dasar-dasar Evaluasi Pendidikan Edisi kedua". Jakarta: Bumi Aksara

Arsyad, Azhar. 2007. "Media Pembelajaran". Jakarta: Rajawali Press.

Candiasa, I Made. 2010. Pengujian Instrumen Penelitian Disertai Aplikasi ITEMAN dan BIGSTEPS. Singaraja: Undiksha Press.

Daryanto dan Herry Sudjendro. 2014. Wacana Bagi Guru, Siap Menyongsong Kurikulum 2013.Yogyakarta: Gava Media.

Jihad, Asep dan Abdul Haris. 2012. Evaluasi Pembelajaran. Yogyakarta: Multi Pressindo.

Kemendikbud. 2014a. Peraturan Menteri Pendidikan dan Kebudayaan Republik Indonesia Nomor 57 Tahun 2014 tentang Kurikulum 2013 SD/MI. Jakarta: Kemendiknas.

Kosasih, E. 2014. Strategi Belajar dan Pembelajaran Implementasi Kurikulum 2013. Bandung: Yrama Widya. 
Koyan, I Wayan. 2012. Statistik Pendidikan Teknik Analisis Data Kuantitatif. Singaraja: Undiksha Press.

Krissandi, Sagita dan Rusmawan. 2015. "Kendala Guru Sekolah Dasar Dalam Implementasi Kurikulum 2013". (Jurnal) FKIP Universitas Sanata Dharma, No. 3.

Kunandar. 2014. "Penilaian Autentik". Jakarta: Grafindo Persada.

Kurniasih, Imas dan Berlin Sani. 2014. "Sukses Mengimplementasikan Kurikulum 2013". Kata Pena.

Kurniasih, Imas dan Berlin Sani. 2015. "Ragam Pengembangan Model Pembelajaran". Kata Pena.

Munirah . 2015. Sistem Pendidikan Di Indonesia: Antara Keinginan Dan Realita . Jurnal Auladuna, Vol. 2 No. 2 Desember 2015: 233-245

Megawati, Priarti. 2012. Meretas Permasalahan Pendidikan Di Indonesia . Jurnal Formatif 2(3): 227-234 ISSN: 2088-351X

Nasrun. 2016."The Use of Cooperative Learning With Numbered Head Together Model to Improve The Student's Mathematics Subject". Journal of Mathematics.Vol 12.

Peraturan Menteri Pendidikan dan Kebudayaan Republik Indonesia Nomor 53 Tahun 2015 Tentang Penilaian Hasil Belajar Oleh Pendidik Pada Pendidikan Dasar dan Pendidikan Menengah. 2015. Jakarta: Kementerian Pendidikan dan Kebudayaan.

Purnomo, Suud. 2012. "Improving The Student' Reading comprehension through Numbered Head Together Technique". Journal on English as a Foreign Language, Vol 2.Tersedia pada http://e-journal.iain-palangkaraya.ac.id

Riastini, Putu Nanci, dkk. 2016. "Pembelajaran IPA di SD". Singaraja: Undiksha.

Ridwanthi, Prima. 2013. "Pengaruh Model Pembelajaran Kooperatif Tipe Numbered Head Together Berbantuan Media Question Card Terhadap Hasil Belajar Matematika Siswa Kelas IV SD N 6 Bondalem". Undiksha, Vol 1. Tersedia pada https://ejournal.undiksha.ac.id

Rimawati, Ema. 2016. Ragam Media Pembelajaran.Kata Pena.

Rusman. 2013. "Model-Model Pembelajaran Mengembangkan Profesionalisme Guru". Jakarta: Grafindo Persada.

Samatowa, Usman. 2016. Pembelajaran IPA Di Sekolah Dasar, Cetakan Ke-3. Jakarta: Indeks

Sanjaya, Wina. 2011. "Strategi Pembelajaran Berorientasi Standar Proses

Pendidikan". Jakarta: Kencana.

Sari.Malda dan Edy Surya. (2017)." Improving the Learning Outcomes of Students using Numbered Heads Together Model in the Subjects of Mathematics" International Journal of Science. Volume 33. No 3(hlm.313)

Shoimin, Aris.2014. "68 Model Pembelajaran Inovatif dalam Kurikulum 2013". Yogyakarta: ARRUZZ MEDIA.

Solihatin, Etin dan Raharjo. 2007. Cooperative Learning Analisis Model Pembelajaran IPS Jakarta : Bumi Aksara.

Suarjana, I Made dan Ngurah Japa. 2015. "Pendidikan Matematika II". Singaraja: Undiksha. 
Sudiman, Arief, dkk. 2005. "Media Pendidikan". Jakarta : Raja Grafindo Persada

Sugiono. 2017. "Metode Penelitian Pendidikan Pendekatan Kuantitatif Kualitatif dan R\&D". Bandung: Alfabeta.

Suriani, Ketut. 2013. "Pengaruh Model Pembelajaran Kooperatif Tipe NHTBerbantuan Media Flip Chart Terhadap Hasil Belajar Ipa Siswa Kelas V SD". Undiksha.Vol 1. Tersedia pada https://ejournal.undiksha.ac.id

Susanto, Ahmad. 2014a. "Teori Belajar \& Pembelajaran di Sekolah Dasar". Jakarta: Kencana Prenada Media Group.

Tegeh, I Made. 2010. "Media Pembelajaran". Singaraja: Undiksha Singaraja.

Trianto. 2009. "Model-Model Pembelajaran Inovatif Berorientasi Konstruktivistik". Jakarta: Pres Pustaka.

Siti, Aas Sholichah. 2018. Teori-Teori Pendidikan Dalam Al-Qur'an . Jurnal Pendidikan Islam Vol.07, No. 1 ISSN : 2252-8970 